\title{
Helicopter Money: The New Form of Monetary Easing in the Eurozone?
}

\author{
Nikolaos A. Kyriazis $^{1}$ \& Emmanouil M. L. Economou ${ }^{1}$ \\ ${ }^{1}$ Department of Economics, University of Thessaly, Greece \\ Correspondence: Emmanouil M. L. Economou, Department of Economics, University of Thessaly, 28 October \\ 78 Street, PC: 38333, Volos, Greece. E-mail: emmoikon@uth.gr
}

Received: December 29, 2016

Accepted: January 25, $2017 \quad$ Online Published: February 15, 2017

doi:10.5539/ijef.v9n3p38

URL: http://dx.doi.org/10.5539/ijef.v9n3p38

\begin{abstract}
Although unconventional measures by the ECB have been very extensive so as to fortify the Eurozone's financial system the question of whether more drastic measures are necessary, is at the forefront of newly aroused academic debate. This paper's main effort is to conceptualize helicopter drops in the Eurozone before hindsight in order to shed some light on how feasible are more drastic measures for the Eurozone and how they could further attenuate moral hazard problems. An early understanding of overt money financing will help in better driving monetary policy and emphasize whether the benefits of more and free money printing could bring about a heal for the wreckages of the EU membership status.
\end{abstract}

Keywords: unconventional monetary policy, helicopter money, European Central Bank

\section{Introduction}

A number of traditional monetary policy tools have been employed by the Eurozone monetary authorities in normal times in order to exercise monetary policy. Interestingly, the European Central Bank (ECB) has been traditionally using a number of interest rates in order to provide liquidity among the member-countries of the Eurozone. The key interest rates for the euro area set by the ECB are: i) the interest rate on the main refinancing operations (MROs) which provides the most of liquidity to the banking system. ii) The rate on the deposit facility, which is used by banks to make overnight deposits with the Euro system. iii) The rate on the marginal lending facility, by which the Euro system offers overnight credit to banks.

Nevertheless, on the wake of the financial crisis that was triggered by the Lehman Brothers collapse in 2008, and the new situation that was terra incognita for European countries, the ECB has preceded to a number of further unconventional monetary policy actions in order to stimulate the economy of the euro area. One of these, is the Corporate sector purchase program (CSPP) that will be carried out by six national central banks acting on behalf of the Euro system, coordinated by the ECB. CSPP aims to provide further monetary policy accommodation and help inflation rates return to levels below, but close to, $2 \%$ in the medium term (Note 1). This has come to be added to the public sector purchase program (PSPP) which was initiated on 9 March 2015 when the Euro system started to buy public sector securities. These securities included nominal and inflation-linked central government bonds, bonds issued by recognized agencies, regional and local governments, international organizations and multilateral development banks located in the euro area. Before these, the asset-backed securities purchase program (ABSPP) started on 21 November 2014, in order to help banks diversify funding sources and to give a stimulus to the issuance of new securities. These securities were intended to help banks provide credit to the real economy (Note 2).

Before that, the Euro system initiated three government bond purchase programs. The first one started on 2 July 2009 and was called CBPP1 (Note 3). It was terminated on 30 June 2010 after reaching a nominal amount of $€ 60$ billion. A second program followed, CBPP2, based on a decision made on 6 October 2011, which the following month was decided by the ECB to have an issue volume of EUR 300 million or more (Note 4). Moreover, it should have a minimum rating of BBB and a maximum residual maturity of 10.5 years, and would be conducted in both the primary and the secondary markets. The third Covered Bond Purchase Program, CBPP3, was decided on 20 October 2014, in order to facilitate credit provision to the real economy and generates positive spillovers to other markets (Official Journal of the European Union, 2014). 
Admittedly, the most-known non-conventional measures of the ECB were: i) LTROs, ii) TLTROs and iii) APP. On 8 December 2011, the ECB took a decision to conduct two longer-term refinancing operations (LTROs) with a maturity of 36 months and the option of early repayment after one year (European Central Bank ECB, 2011). Moreover, liquidity-providing long-term refinancing operations in euro with a 3-year maturity (on 29 January 2015 and 26 February 2015 maturity) were decided, as well as by US dollar liquidity-providing operations. TLTROs were the targeted longer-term refinancing operations to provide financing to credit institutions for up to four years' periods by offering long-term funding at favorable conditions. Additionally, Asset Purchases Programs (APP) have been implemented in order to sustain growth across the Eurozone and with the intention of keeping inflation rates lower but not far from the $2 \%$ target in the medium run (Note 5).

The aim of this paper is not only to walk along the same thread of the voluminous Quantitative Easing (QE) literature, but to take a quantum leap forward. Therefore, to examine whether a new form of unconventional monetary policy could be implemented and render stimulatory enough in the Eurozone. The overt money financing, most known as "helicopter money" can only act as an amalgam of monetary and fiscal policy. The aim of this study is to cast light on the innovative but rather mischievous nature of helicopter non-irredeemable liquidity injections that arouses moral hazard incentives and problems in risk-sharing. Specifically, we put the spotlight on special Eurozone characteristics and in potential complementary or substitution effects of overt money printing with wealth effects in member-countries.

In contrast to trends about $\mathrm{QE}$ exit strategies in recent academic work, this paper aims to bolster interest in further and more drastic unconventional monetary policy actions and finds merit in examining the suitability of breakthrough measures when the Eurozone economy is in dire straits. In a nutshell, we reexamine activist policies in the same vein as Buiter (2005), but in a much more synchronous framework.

The remainder of this paper is organized as follows. Section 2 provides a review of econometric results on studies about QE. Section 3 analyzes the reasons for which unconventional monetary policy and more specifically, helicopter money, are important nowadays. In Section 4, the determinants of overt money financing are examined. Section 5 offers a thorough examination of the special fiscal-linked character of helicopter money and its potential of threatening the ECB's credibility and Section 6 discusses the perspectives of unconventional monetary practices. Section 7 concludes.

\section{Literature Review on QE Econometric Studies}

A vast literature has focused on unconventional monetary practices since the Lehman Brothers collapsed in 2008 in the US, the UK, and Japan. Nevertheless, the majority of studies concerning the Eurozone have been more recent since non-conventional monetary practices by the ECB were applied with delay compared to the rest of the world (especially the US and the UK). Unconventional monetary policies are mainly transmitted to the economy through some specific channels. The most well-known and perhaps the most effective of all is the portfolio rebalancing channel (Meaning \& Zhu, 2011; Chung et al., 2011; Fratzcher et al., 2013; Gagnon et al., 2011; Ellison \& Tiscbirek, 2014; Joyce \& Tong, 2012; Christensen \& Rudebusch, 2012; Falagiarda \& Reitz, 2015).

By this channel, lowering of bond yields takes place through lowering term premia (duration risk channel) and yields on long-term risky assets (safety premium channel), as well as decreasing the cost of accessing credit in financial markets. Lower term premia increase wealth, and lower cost for credit in the form of lower credit premia, both have a positive effect on demand. Moreover, the bank lending channel allows credit to affect the real economy (Curdia \& Woodford, 2011; Goodhart \& Ashworth, 2012; Lyonnet \& Werner, 2012; Gertler \& Karadi, 2013; Carpenter et al., 2014; Hannikainen, 2015). Specifically, it aims to increase bank deposits and liquid assets, thereby providing higher availability of bank credit in order to inject liquidity into the economy. This way, there is a spur on aggregate demand. If inflows to financial institutions are long-term, this helps banks to expand their lending. The confidence channel is also of high importance (Roache \& Russett, 2013; Lutz, 2015; Chen et al., 2016; Lim \& Mohapatra, 2016).

Moreover, communication by monetary authorities with economic units is of high importance, the so-called "signaling channel" (Krisnamurthy \& Vissing-Jorgensen, 2011; Swanson, 2011; Christensen \& Rudebusch, 2012; d' Amico et al., 2012; Bauer \& Neely, 2013; Chanda \& Waters, 2014; Kenourgios, 2015a,b). This means that unconventional monetary policy serves as a credible commitment to maintain interest rates at low levels even when the economy has recovered. Thereby, purchasing long-term assets by QE makes them appear as credibly committing to low interest rates. When it comes to the liquidity channel, by providing liquidity to investors, QE leads to lower liquidity premiums for bonds (Chanda \& Waters, 2014; Carpenter et al., 2014; Christensen \& Gillan, 2016; and Kiendrebeogo, 2016). 
Particularly, the yield of less liquid assets decreases in comparison with most liquid assets. Another unconventional transmission channel is the prepayment risk one as in Stroebel and Taylor (2012), where QE lowers the risk premium that depends on how much prepayment risk the mortgage investors bear and has to do with Mortgage-Backed Securities (MBS) yields. Other channels used in the new unconventional era is the default risk channel where QE by causing a positive effect on the economy lowers the default risk premium of firms, as well as the inflation channel, where interest rate uncertainty and inflation expectations fall due to central bank actions.

Important econometric results are derived from papers studying the portfolio rebalancing effects. In Meaning and Zhu (2011), an event study methodology is adopted for the US and the UK and bond yields are found to have declined across maturities, mostly the 5- and 10-year yields. There was a 63 basis points (bp) fall in US lower-grade (BBB) bond yields and about $100 \mathrm{bp}$ in two days after the first round of Large Scale Asset Purchases (LSAP1) was announced. Announcements about the first round of Asset Purchase Facilities APF1 in the UK led to a $56 \mathrm{bp}$ and a $96 \mathrm{bp}$ fall respectively. When it comes to Chung et al. (2011), by building a model of portfolio-balance effects it is shown that lower long-term interest rates in the US produce higher stock market valuations and a modest devaluation of the dollar.

Moreover, simulations give evidence that asset purchases have contributed significantly to price stability. Moreover, Fratzcher et al. (2013) use regression techniques and study the spillover effects of the US unconventional policy. They argue that Fed measures during QE1 were very effective in lowering sovereign yields and stimulating equity markets in the USA and in other 65 countries. Furthermore, Gagnon et al. (2011) adopt an event-study for the estimation of the impact of Fed's purchases from 2008 to 2010. They argue that a 1\% increases in the unemployment gap, the core CPI inflation, inflation disagreement, and realized volatility increase the term premium about 20,30,40, and 100 basis points (bp) respectively.

Ellison and Tischbirek (2014) use calibration for US in the model constructed and claim that LSAPs could be effective even with positive nominal interest rates, in order for inflation as well as output to be stabilized. Moreover, Christensen and Rudebusch (2012) analyse how the announcements by the Fed and the BOE of buying longer-term government debt affected the declines in government bond yields and find that $\mathrm{QE}$ had an impact in the UK entirely through reductions in the term premiums. Furthermore, portfolio balance effects differ between the two countries due to their market structures. When it comes to the ECB, Falagiarda and Reitz (2015) support that the Security Market Programme (SMP) events have the highest cumulative effect on the Greek, Italian and Spanish spread.

Studies based on bank lending channel effects also exhibit important results. Lyonnet and Werner (2012) employ the Hendry methodology for the UK and argue that QE is effective on nominal GDP and that the Bank of England (BOE) should target directly to the growth of bank credit for GDP transactions. When it comes to Gertler and Karadi (2013), by model simulations find that the central bank can indeed have a stimulatory impact on the economy due to its asset purchase activities, as it can obtain funds elastically and reduce credit costs in the economy.

The longer is the horizon of the Zero Lower Bound (ZLB), the more effective the QE is found to be. By using a New Keynesian model, Curdia and Woodford (2011) find that targeted purchases by the central bank could indeed have an impact when financial markets are disrupted, that is only when private markets cannot eliminate most of the potential gains from trade in financial instruments. Carpenter et al. (2014) by using panel data argue that the bank-based non-standard measures in the US and the Eurozone eased conditions in money markets and that this led to an increase in business lending by banks. For his part, Hannikainen (2015) by adopting regression techniques finds that the predictive content of the term spread has changed since the onset of ZLB/unconventional monetary policy and is not suitable for predictions during conventional monetary policy.

Confidence channel-based academic work has also interesting findings to exhibit. Specifically, Chen et al. (2015) by applying a Generalized Vector Error Correction Model (GVECM) find that QE measures that lower the US corporate spread have had large effects, with large variations across regions and individual economies. Counterfactual analysis indicates that US QE measures have supported the advanced economies and prevented potential recession and deflation. When it comes to Lutz (2015), by employing panel-VAR finds that the ECB unconventional monetary policy reduced the bank funding risks, thereby leading to greater money market resilience.

The signaling channel effects are also shown in important studies. Interestingly, Kenourgios et al. (2015a) employ an APARCH methodology examine how QE announcements by the ECB, the BOJ and the BOE have affected exchange rate dynamics and find that monetary easing policies vary regarding their credibility and 
effectiveness. In the same vein, Kenourgios et al. (2015a) by a similar methodology argue that that the volatility of EUR and JPY is getting higher over the periods of unconventional monetary. Moreover, Swanson (2011) by an event-study supports that the "Operation Twist" had a significant effect on longer-term Treasury yields, whereas the cumulative effect of six QE announcements on longer-term Treasury yields is about $15 \mathrm{bp}$.

Studies where the liquidity channel is important further shed light on understanding QE effects. Christensen and Gillan (2016) claim that QE is more effective on Eurozone countries due to less liquid sovereign bond markets. Furthermore, QE effectiveness could be influenced according to the time frame, purchase pace, and the targeted security classes. When it comes to Kiendrebeogo (2016), he supports that US QE leads to increased net portfolio flows to developing countries, and to non-conventional monetary policy advanced economies to a lesser extent.

\section{Importance of Non-Conventional Policies and Helicopter Money}

Unconventional monetary policies have been at the center of economic debate since the onset of the recent financial crisis in 2008. In the beginning, the detachment from the steady inflation and GDP growth targeting as indicated by the Taylor rule, seemed inevitable in order to spur economic activity and confront the zero-lower bound stagnation. The enlargement of central banks' balance sheets looked as being inevitable in order to surpass the conventional monetary policies' rigidities (Sheel, 2015).

This new form of monetary practices took primarily two forms. The first one was quantitative easing. QE is expressed as an increase in the size of the central bank balance sheet through an increase in its monetary liabilities (Borio \& Disyatat, 2010; Ricketts, 2011). The second form was called "qualitative" or "credit" easing and focused on altering the composition of the central bank's balance sheet (Kawai \& Takagi, 2012; Tuckwell \& Mendonça, 2016). It was most employed by the U.S. Fed.

Although these policies were considered as the final arrow that remained in the quiver of monetary authorities in order to steer economic recovery efforts, there is currently some belief that further stimulatory measures could be taken, widely known as "helicopter money". This term was first pronounced by Milton Friedman in his 1969 book with the title The Optimum Quantity of Money: "Let us suppose now that one day a helicopter flies over this community and drops an additional $\$ 1000$ in bills from the sky...Let us suppose further that everyone is convinced that this is a unique event which will never be repeated" (Freedman [1969], 2005).

Friedman had defined "helicopter money" as a non-reversible rise in the nominal stock of fiat base money rate, constrained by the intertemporal budget of the monetary authorities and the government. QE forms an example of such as a policy conducted by open-market purchases of sovereign debt by the central bank, a debt of a non-monetized form. What helicopter money drops pursue is a stimulus to aggregate demand, primarily through an urge to private demand. Immense liquidity offering fits well in conditions where rates have reached the zero lower bound, thus have become ineffective. Consequently, unconventional monetary policies constitute a good solution in an effort to counterbalance the inactiveness of interest rates. According to Friedman, government should never leave the economy surrender to deflationary pressures, so necessary measures have to be taken at the right moment.

Regarding the way monetary and fiscal policy are expressed under this new policy, helicopter money could show up in the form of transfer payments or tax cuts to private households and firms. In other words, fiscal policy should be financed by monetary policy, through an enlargement of the monetary base, with liquidity being irredeemable with respect to the private sector. This way, high-powered money could flow into households and businesses in a purely beneficial way. This could be supplementary to the well-known quantitative easing policy, that works through open-market purchases of sovereign debt in the form of government bonds and expands the central bank's balance sheet and so boosts liquidity dynamics.

In tandem with QE pros and cons, helicopter money should never be a first-resort or a second-resort policy, but only an ultimate liquidity-injecting measure. In this manner, moral hazard incentives on the part of economic agents and legislators would be alleviated and the threatening of central bank independence would be much milder. One has to keep in mind that independence constitutes a very important factor concerning the credibility of monetary authorities, and helps the public form rational expectations that contribute to achieving the desired policy results.

Fed's former president Ben Bernanke has also been a supporter of "helicopter money". This was the reason he was given the nickname "Helicopter Ben" (Buiter, 2014). He has declared that outright money creation by the central bank could effectively replace the funding of fiscal deposits by the Fed buying government bonds. This economic boost could be promisingly used to ameliorate public infrastructure and reduce the private household debt. Helicopter money is believed to motivate banks not to hold the liquidity injected in the form of reserves. If 
it did, this would inevitably slow down the money multiplier's velocity.

Helicopter money is also believed not to be wasted because it works both through the channel of monetary base growth but also through the money multiplier development. In other words, this extra cash could be rolled over by the monetary authorities by allocating new treasury bonds at the central bank. The alternative way to keep the excessive liquidity inside the financial system, is by the conduct of reverse repo operations. If helicopter money worked properly, economic agents' awareness of money injection permanency would enhance public expenditure growth and extend credit without the peril of high leverage neither bubble-creation phenomena occurring (Buiter, 2005).

\section{Determinants of Helicopter Money}

According to Bernanke $(2002,2003,2016)$ a valuable advantage of helicopter money is its capacity of being effective in conditions of an alarmingly high government debt. He notes though that such a policy would be in need of coordination between monetary and fiscal authorities as well as a synchronization of their policies. Unfortunately, this is far from easy to be achieved, as also is the harmonious matching of a groundbreaking policy like helicopter drops with conventional policies.

This forms the reason why the practice of helicopter money offering did not tend to present a significant possibility of being applied in the U.S. Money-Financed Fiscal Programs (MFFP) as Bernanke prefers to name it It works by the Treasury proceeding to public spending and tax discounts, where the increase in government deficit is not financed by new public debt issuance to taxpayers. Instead, this new spending would be feasible by the central bank crediting the government with the corresponding amount of money in the government's "checking account" at the Bank.

A different option, yet a tantamount one, would be the government issuing the respective money in debt and the central bank to reconcile with the idea of the indefinite time horizon character of this debt. Any debt earned by monetary authorities should be attributed back to the government. The central bank's commitment that monetary policy will never be altered is of primary importance in either occasion, in order for the central bank to preserve its character of trustworthiness.

The effectiveness of helicopter money could be ensured only through the following channels: first, provided that it will increase public expenditure, thereby boosting production, income and employment. Moreover, by having a positive impact on households' propensity to consume, motivated by increased income made disposable by tax cuts. It has to be bared in mind, that a further way to urge economic growth is by expectations of a higher inflation due to liquidity injections, which result in a lower real interest rate and provide motivation for higher investment levels (Buiter, 2014). Last but far from least, lie the credibility and stability characteristics of such a policy, as citizens have to know with certainty that no tax charges will be passed over to the next generation. Obviously, it is this that could motivate them to proceed to expenditures and let the expansionary dynamics work in favor of the economy.

Strict conditions for helicopter drops' efficacy mostly extend on a three-pillar basis. First, paper base money should bring benefit for its holder, regardless of its monetary rate of return. As other non-monetary assets are preferable as a storing-value tool and provide a risk-free nominal interest rate, this assumption has to hold for fiat money to be willingly held by the public. Differently said, if base money only served as a "numeraire" and nothing further, helicopter money could have no effect on the economy.

Furthermore, this cash should be non-redeemable, meaning that the monetary authorities should let the liquidity offered to stay permanently in the financial system, in order to achieve a remarkably higher efficiency level. These extra funds should not be a liability for its new owner (Buiter, 2003). Under these conditions, they could possess a demand-spurring asset through their lives, not only temporarily. This is where much of the difference with bond financing in QE operations lies. Moreover, interest rates at which money is priced should be over zero, otherwise demand effects on GDP growth will always remain negligible. Logically, this would be the only way for stimulating the money multiplier and putting in motion dynamics of escape from the liquidity trap.

Helicopter money's influence depends on whether state-issued fiat money, despite being an "inside asset", is really a net wealth for the private sector. Under the aforementioned condition of irredeemability, helicopter drops can have an impact on the economy through the wealth effect channel or the real balance channel. If households hold this money with no production costs despite its zero nominal rate, and prefer it to other interest-bearing assets, demand could be boosted. For helicopter money not to be just recycled in the economy, but to have real stimulatory effects, it has to be considered as an exogenous asset. Solvency constraints of the public as well as of the private sector should always be taken into consideration. In order for extra cash to spur consumption demand, 
the Ricardian equivalence should not matter. In other words, households have to be certain for the non-emergence of future tax burdens due to this freshly-pumped liquidity. This is where this permanent cashless money's advantage can enter the household utility framework. Non-redeemability ensures that net wealth will always be positive for households.

The extra benefit that could derive from overt money financing, as helicopter money is used to be called, is that it could lessen the risk incorporated in quantitative easing policies, as its supporters claim. No money would have to be swept up in the end of unconventional monetary policy, thus the probability of deflationary pressures making their appearance would get extremely lower. Differently said, its character would be beneficial even for the period when the central bank balance sheet would be diminishing. In this mentality, it could be arguably supported that helicopter money is an extension of the notion of QE, having the permanency characteristic added in liquidity injections.

The focus of crisis-fighting strategies on the demand side rather on supply-side policies, which has been made by supporters of helicopter drops, has the synchronized cooperation between fiscal and monetary authorities as its main axis (Bernanke, 2002, 2016). Whether central banks lose part of their authority territory or not, will be discussed later on. Nevertheless, the irreversibility of new money stock creation brings on the forth a number of overt money characteristics that could legitimize this theory as a candidate one to be implemented nowadays. As it has already been supported (Note 6), a combination of monetary and fiscal policy has the greatest feasible increasing impact on demand and output. Moreover, they can fight secular stagnation in a high level of efficacy.

Another crucial feature is the ability to quickly raise people's marginal propensity to consume, namely to augment goods' prices and thereby inflation in a very short time. This indicates money's ability to escape from the deflationary straights that crises impose. On the other hand, interest rates remain low, so there is low risk of the private sector shrinking.

\section{The Quasi-Fiscal Central Bank's Role and Its Independency}

No matter how independent a central bank might be, the government has the right to receive its net profits. The European Central Bank is distinguishable from other central banks in that it is owned by the national central banks of the euro-area member states. One should bear in mind that each country's government has the administrative rights of its corresponding monetary authorities. When fiscal dominance is the rule and monetary dominance is the exception, could the ECB be the exception nowadays?

Despite having to come in compliance with national fiscal authorities, and keeping in mind that they are separated and distinct by national boundaries, the ECB's operational independence could be characterized as high. Not being obliged to take instructions from Union institutions or bodies, or from any government of a Member state, the ECB could fight the time-inconsistency that employment-oriented governments provoke, so it could reduce the "inflationary bias" of its policy (Eijffinger, 2007).

Nowadays, the concept of a common central bank gets wider than its traditional view. Apart from being responsible for conventional and unconventional monetary policies and serving as a lender of last resort in the case of financial crises, now multi-partied monetary authorities acquire a quasi-fiscal role. Apparently, by applying helicopter money drops as a breakthrough action to spur aggregate demand, the central bank will tend to play a macro prudential role. Thereby, it will be assigned with political duties, such as imposing taxes in an indirect way. This kind of action would mutate its role as defined by the Treaty of the EU (Note 7). According to the Article 127 of the European Treaty (Note 8), the primary objective of the European System of Central Banks is to maintain price stability.

Moreover, in Article 123 (Note 9) of the same Treaty it is stated that: "Overdraft facilities or any other type of credit facility with the European Central Bank or with the central banks of the Member States (hereinafter referred to as national central banks") in favor of Union institutions, bodies, offices or agencies, central governments, regional, local or other public authorities, other bodies governed by public law, or public undertakings of Member States shall be prohibited, as shall a purchase directly from them by the European Central Bank or national central banks of debt instrument". A remedy for the Eurozone should better not be averse to these articles.

Different proposals could include that monetary authorities could be part of an organization such as the Supreme Financial Stability Council (FSOC), so as only to have a consulting role to governments. A great disadvantage of a potential triple mandate of monetary authorities (adding fiscal responsibilities to price stability and employment encouragement), would entrain some malfunctions. Should a central banker be in charge of regulatory affairs, it would be really difficult to be dismissed, because it would be unlikely that he performed 
poorly in all of his responsibilities. Differently said, he could mitigate his failure in one domain with his success in another and keep his job. Nevertheless, poor performance in either of the two sectors of his responsibility would reduce overall economic efficiency, with no punishment. Moral hazard incentives would likely strengthen and the economic system would confront a difficulty in diversifying that source of risk in the policies affecting it.

In other words, accountability in policy-making has to be closely connected with the tasks being distinctive and with independence of responsibilities across domains. In the near past, the ECB had to write to the European Parliament, the European Council and the European Commission about its actions. Since 2015, the ECB has initiated the publishing of its policy meetings, whereas votes on decision-making still do not get published. The ECB has a special character. Additionally, it is highly possible that a substantial amount of pressure is exercised on each national central banker by the political authorities in each country. This is the reason why the independence of the ECB in the Eurozone has to be fortified in a larger extend than in any other region in order to withstand this large scope of differently initiated and oriented streams of pressure. Transparency problems are greater when a group rather than a sole organization has to make a decision, as conflicts of power can lead to a large set of inefficient equilibria, but no commonly accepted efficient ones.

By taking into consideration the nowadays European sovereign debt crisis and increased inflationary pressures by indebted member-countries, the achievement of central bank independence is likely to be even more difficult. Moreover, the great difficulty compared to a national central bank has to be taken into consideration by supporters of alterations in the ECB's mandate, as regards amending the European Treaty that defines the ECB's and the Euro system tasks. Furthermore, legal tenders will probably have a hard time to efficiently withstand the political pressure, as has been the case many times in the past.

\section{Perspectives of Unconventional Monetary Policies}

It is highly debatable whether unconventional monetary actions have been as effective as expected, as doubts have risen regarding the efficacy of trillions of euros injected into the Eurozone's financial system during the first year of QE by the ECB (Levren, 2016). When it comes to modern monetary theory, neo-chartalistic views closely connected to overt monetary financing demand a tight cooperation between the government and the central bank (Lavoie, 2016), or the government taking on full monetary sovereignty and printing money to cover deficits. The special framework distinguishing monetary from fiscal authorities' duties would have to be even more distinct and strict for the multi-economy composed Eurozone in order to be effective.

Permanent fiat-money issuing would have to be legitimized by European citizens (through their governments' approval) and be the result of careful decision-making. The monetary wealth induced by the sudden and sharp liquidity injections, could perhaps raise current and future consumption levels in a beneficial way. Gresham's Law prevailing is far from what the Eurozone needs in a period of crisis, and this is the reason why money's nominal value should not fall too disproportionally in comparison to its intrinsic value.

It is noteworthy that disinflation in Europe and the inherent tendency of the EU towards the "flight-to-safety" due to the leading role of Germany, have made the Eurozone (EZ) be firm in its risk-averting behavior, in order to preserve the highly independent character of the European monetary authorities. This way, though, the ECB's dual mandate becomes more favorable of stability, to the detriment of its other pillar, that is employment, thus keeping rates lower from the $2 \%$ target. This self-perpetuating safety preference it presents, is enhanced by lower inflation that increases the real interest rate, which leads to the continuation of the flight-to-safety tendency.

Excessive attractiveness of safe assets, as money and government bonds are considered reduces investing incentives and makes risk in more aggressive investments not to be worth taking. European markets are highly efficient but not highly profitable, weakening their stimulatory perspectives. Strict legislation imposed by highly transparent and independent authorities make good-quality collateral to be highly-demanded because of its necessity for meeting any imposed liquidity standards, such as those indicated by the Basel Accord (Basel III) (Note 10). Deflationary pressures render this risk-averting expectations sentiment easier to be strengthened.

Supporters of innovative unconventional monetary policies would claim that the dilemma of letting or preventing risky private debt from entering the central bank's balance sheet softens when permanent money drops show up. They could argue that because of the Euro system having made significant marked-to-market losses on loans against junk collateral and lacking a mechanism to recapitalize it as a whole, something radical has to be done to set the EZ's financial engine into motion.

Restoration of confidence in debt sustainability within Europe, demands measures for risk-sharing among Eurozone counterparties, but without hurting their financial health, nor creating cost-benefit imbalances. Better 
said, the narrowing of sovereign spreads should take place by effective national aggregate demand increases and not by focusing just on how to share the cost of recapitalization. Quantitative easing and helicopter money are believed by their supporters to offer such an opportunity, without claiming to deserve a title of perfection, but perhaps by inducing a significant amelioration.

In a bank-centric economic construction such as the EZ, liquidity is needed very intensely, if there is lack of a better way to function. Large money injections would push the euro towards depreciation and raise exports, thereby triggering the economy. Confidence could begin to be restored, and expectations would not be pessimistic anymore. The consequent decline in risk-aversion would boost loans, and lower lending rates could put more fuel into the Eurozone's consumption-hungry financial engine.

On the other hand, it is highly debatable whether monetary authorities' effectiveness could survive for long if their credibility would be lost. Although helicopter money could probably provoke a stimulus for the Eurozone in the short or medium run, there is a risk of really bad consequences in the longer-run. This could be claimed to be a strong argument against innovative unconventional policies, as the fear of future harsh consequences of money injections is far from negligible. A highly frequent discretionary type of monetary policy could deprive the euro area from stability in its character. The use of wide liquidity provisions could prove difficult not to strengthen adverse incentives. Moreover, private sector's expectations could render totally insensitive to the ECB's announcements if large volumes of liquidity had been offered and its trustworthiness had become low.

\section{Conclusion}

This article describes the unconventional monetary policies that the ECB has adopted but also examines the innovative character and the necessity of a new means of liquidity providing, such as helicopter money that has spurred an increasing volume of debate nowadays. The main advantages of overt money financing, as helicopter drops are used to be called, is the potential permanency of the stimulus they could provide due to non-irredeemability are under scrutiny here. On the other hand, the probability that free amounts of money could turn the ECB into playing a quasi-fiscal role, which comes to contrast with its mandate and hurts its independence. These are discussed, willing to cast light on the double-edged sword character of excessive liquidity provisions' effectiveness.

The main question that we aim to help in replying is: does the drastic character of helicopter money drops help in getting away from the onerous liquidity trap? Could this ever prove more dangerous in the longer-run than the current situation or should rigorous and breakthrough measures always be applied in exceptional times? In this paper, we highlight the most noteworthy characteristics of overt money financing that was expressed by Friedman, Bernanke, and align with modern money theory. The aim of this study is to contribute to a better understanding of the nowadays intense dilemma between flexibility and stability free from any prejudice and provide stimulus for further thinking for policymaking.

\section{References}

Bauer, M. D., \& Neely, C. J. (2014). International channels of the Fed's unconventional monetary policy. Journal of International Money and Finance, 44, 24-46. https://doi.org/10.1016/j.jimonfin.2013.12.007

Bernanke, B. S. (2002). Deflation: Making sure it doesn't happen here (No. 530). Board of Governors of the Federal Reserve System (US). Retrieved from https://www.federalreserve.gov/boarddocs/Speeches/2002/20021121/default.htm

Bernanke, B. S. (2003). Some thoughts on monetary policy in Japan: Remarks before the Japan Society of Monetary Economics. Tokyo, Japan, the Federal Reserve System, 2003. Retrieved from http://www.federalreserve.gov/BOARDDOCS/SPEECHES/2003/20030531/default.htm

Bernanke, B. S. (2016). What tools does the Fed have left? Part 3: Helicopter money. Brookings Institution, $2016 . \quad$ Retrieved from https://www.brookings.edu/blog/ben-bernanke/2016/04/11/what-tools-does-the-fed-have-left-part-3-helicop ter-money

Borio, C., \& Disyatat, P (2010). Unconventional monetary policies: An appraisal. BIS Working Papers, 292, Bank for International Settlements, 2010. https://doi.org/10.1111/j.1467-9957.2010.02199.x

Buiter, W. H. (2003). Helicopter Money: Irredeemable Fiat Money and the Liquidity Trap. NBER Working Paper No. 10163, National Bureau of Economic Research, 2003. https://doi.org/10.3386/w10163

Buiter, W. H. (2005). New developments in monetary economics: Two ghosts, two eccentricities, a fallacy, a mirage and a mythos. The Economic Journal, 115(502), 1-31. 
https://doi.org/10.1111/j.0013-0133.2005.00978.x

Buiter, W. H. (2014). The simple analytics of helicopter money: Why it works-always. Economics, 8, 2014. https://doi.org/10.5018/economics-ejournal.ja.2014-28

Carpenter, S., Demiralp, S., \& Eisenschmidt, J. (2014). The effectiveness of non-standard monetary policy in addressing liquidity risk during the financial crisis: The experiences of the Federal Reserve and the European Central Bank. Journal of Economic Dynamics and Control, 43, 107-129. http://dx.doi.org/10.1016/j.jedc.2014.03.005

Chadha, J. S., \& Waters, A. (2014). Applying a macro-finance yield curve to UK quantitative Easing. Journal of Banking \& Finance, 39, 68-86. http://dx.doi.org/10.1016/j.jbankfin.2013.11.008

Chen, Q., Filardo, A., He, D., \& Zhu, F. (2016). Financial crisis, US unconventional monetary policy and international spillovers. Journal of International Money and Finance, 67, 62-81. http://dx.doi.org/10.1016/j.jimonfin.2015.06.011

Christensen, J. H., \& Rudebusch, G. D. (2012). The response of interest rates to US and UK quantitative easing. The Economic Journal, 122(564), 385-414. https://doi.org/10.1111/j.1468-0297.2012.02554.x

Christensen, J., \& Gillan, J. M. (2016). Does quantitative easing affect market liquidity? Federal Reserve Bank of San Francisco. Retrieved from http://www.frbsf.org/economic-research/files/wp2013-26.pdf

Chung, H., Laforte, J. P., Reifschneider, D., \& Williams, J. C. (2011). Estimating the macroeconomic effects of the Fed's asset purchases. FRBSF Economic Letter, 3. Retrieved from http://www.frbsf.org/economic-research/publications/economic-letter/2011/january/macroeconomic-effectsfed-asset-purchases/

Curdia, V., \& Woodford, M. (2011). The central-bank balance sheet as an instrument of monetary policy. Journal of Monetary Economics, 58(1), 54-79. http://dx.doi.org/10.1016/j.jmoneco.2010.09.011

D’ Amico, S., English, W., López-Salido, D., \& Nelson, E. (2012). The Federal Reserve's Large-scale Asset Purchase Programmes: Rationale and Effects. The Economic Journal, 122(564). http://dx.doi.org/10.1111/j.1468-0297.2012.02550.x/full

Eijffinger, S. C. (2007). Treaty reform: Consequences for monetary policy. Intereconomics, 42(6), 311-316. https://doi.org/10.1007/s10272-007-0232-9

Ellison, M., \& Tischbirek, A. (2014). Unconventional government debt purchases as a supplement to conventional monetary policy. Journal of Economic Dynamics and Control, 43, 199-217. http://dx.doi.org/10.1016/j.jedc.2014.03.012

European Central Bank. (2011). Announces measures to support bank lending and money market activity, 8 December 2011. Retrieved from https://www.ecb.europa.eu/press/pr/date/2011/html/pr111208_1.en.html

Falagiarda, M., \& Reitz, S. (2015). Announcements of ECB unconventional programs: Implications for the sovereign spreads of stressed euro area countries. Journal of International Money and Finance, 53, 276-295. http://dx.doi.org/10.1016/j.jimonfin.2015.02.005

Fratzscher, M., Lo Duca, M., \& Straub, R. (2013). On the International Spillovers of US Quantitative Easing (No. 1304). DIW Berlin, German Institute for Economic Research. https://doi.org/10.2139/ssrn.2276855

Friedman, M. ([1969], 2005). The optimum quantity of money. New Jersey.

Gagnon, J., Raskin, M., Remache, J., \& Sack, B. (2011). The financial market effects of the Federal Reserve's large-scale asset purchases. International Journal of Central Banking, 7(1), 3-43. Retrieved from http://www.ijcb.org/journal/ijcb11q1a1.pdf

Gertler, M., \& Karadi, P. (2013). Qe 1 vs. 2 vs. 3...: A framework for analyzing large-scale asset purchases as a monetary policy tool. International Journal of Central Banking, 9(1), 5-53. Retrieved from http://www.ijcb.org/journal/ijcb13q0a1.htm

Goodhart, C. A., \& Ashworth, J. P. (2012). QE: A successful start may be running into diminishing returns. Oxford Review of Economic Policy, 28(4), 640-670. https://doi.org/10.1093/oxrep/grs034

Hännikäinen, J. (2015). Zero lower bound, unconventional monetary policy and indicator properties of interest rate spreads. Review of Financial Economics, 26, 47-54. http://dx.doi.org/10.1016/j.rfe.2015.03.002

Joyce, M. A., \& Tong, M. (2012). QE and the gilt market: A disaggregated analysis. The Economic Journal, 122(564), 348-384. https://doi.org/10.1111/j.1468-0297.2012.02552.x 
Kawai, K., Morgan, P. J., \& Takagi, S. (2012). Monetary and currency policy. Management in Asia, Cheltenham: Edgar Elgar Publishing. https://doi.org/10.4337/9780857933355

Kenourgios, D., Papadamou, S., \& Dimitriou, D. (2015a). Intraday exchange rate volatility transmissions across QE announcements. Finance Research Letters, 14, 128-134. http://dx.doi.org/10.1016/j.frl.2015.05.007

Kenourgios, D., Papadamou, S., \& Dimitriou, D. (2015b). On quantitative easing and high frequency exchange rate dynamics. Research in International Business and Finance, 34, 110-125. http://dx.doi.org/10.1016/j.ribaf.2015.01.003

Kiendrebeogo, Y. (2016). Unconventional monetary policy and capital flows. Economic Modelling, 54, 412-424. http://dx.doi.org/10.1016/j.econmod.2016.01.008

Krishnamurthy, A., \& Vissing-Jorgensen, A. (2011). The effects of quantitative easing on interest rates: Channels and implications for policy (No. w17555). National Bureau of Economic Research. https://doi.org/10.3386/w17555

Lavoie M. (2013). The monetary and fiscal nexus of neo-chartalism: A friendly critique. Journal of Economic Issues, 47(1), 1-32. https://doi.org/10.2753/JEI0021-3624470101

Lim, J., Mohapatra, S., \& Stocker, M. (2014). Tinker, Taper, QE, Bye? The Effect of Quantitative Easing on Financial Flows to Developing Countries. Policy Research Working Paper. The World Bank. Development Prospects Group. Global Macroeconomics Unit. https://doi.org/10.1596/1813-9450-6820

Lutz, C. (2015). The impact of conventional and unconventional monetary policy on investor sentiment. Journal of Banking \& Finance, 61, 89-105. http://dx.doi.org/10.1016/j.jbankfin.2015.08.019

Lyonnet, V., \& Werner, R. (2012). Lessons from the Bank of England on 'quantitative easing'and other 'unconventional'monetary policies. International Review of Financial Analysis, 25, 94-105. http://dx.doi.org/10.1016/j.irfa.2012.06.002

Meaning, J., \& Zhu, F. (2011). The impact of recent central bank asset purchase programmes. BIS Quarterly Review. Retrieved from http://www.bis.org/publ/qtrpdf/r_qt1112h.pdf

Official Journal of the European Union. (2014). Decision of the European Central Bank of 15 October 2014 on the implementation of the third covered bond purchase programme, (2014/828/EU). Retrieved from https://www.ecb.europa.eu/ecb/legal/pdf/oj-jol_2014_335_r_0010-en-txt.pdf

Ricketts, L. R. (2011). Quantitative Easing explained. Economic Information Letter, Liber 8, 2011. Retrieved from https://research.stlouisfed.org/pageone-economics/uploads/newsletter/2011/201104.pdf

Roache, S. K., \& Rousset, M. V. (2013). Unconventional Monetary Policy and Asset Price Risk (No. 13/190). International Monetary Fund. https://doi.org/10.5089/9781484383230.001

Sheel, A. (2011). Quantitative easing and the helicopter drop. Economic \& Political Weekly, 50(11), 37. Retrieved from http://www.epw.in/journal/2015/11/perspectives/quantitative-easing-and-helicopter-drop.html

Stroebel, J., \& Taylor, J. B. (2012). Estimated Impact of the Federal Reserve's Mortgage-Backed Securities Purchase Program. International Journal of Central Banking. Retrieved from http://www.ijcb.org/journal/ijcb12q2a1.pdf

Swanson, E. T. (2011). Let's twist again: A high-frequency event-study analysis of operation twist and its implications for QE2. Brookings Papers on Economic Activity, 2011(1), 151-188. https://doi.org/10.1353/eca.2011.0006

Tuckwell, C., \& Mendonça, A. (2016). The Global Crisis and Unconventional Monetary Policy: ECB versus Fed. Working Paper CEsA CSG 141/2016. Retrieved from http://pascal.iseg.utl.pt/ cesa/images/files/wp141.pdfon

Van Lerven, F. (2016). Quantitative easing in the Eurozone: A one-year assessment. Intereconomics, 51(4), 237-242. http://dx.doi.org/10.1007/s10272-016-0608-9

\section{Notes}

Note 1. https://www.ecb.europa.eu/mopo/implement/omt/html/index.en.html

Note 2. https://www.ecb.europa.eu/mopo/implement/omt/html/index.en.html 
Note 3. https://www.ecb.europa.eu/ecb/legal/pdf/1_17520090704en00180019.pdf

Note 4. https://www.ecb.europa.eu/press/pr/date/2011/html/pr111103_1.en.html

Note 5. https://www.ecb.europa.eu/mopo/implement/omo/html/index.en.html

Note 6. http://voxeu.org/article/helicopter-money-today-s-best-policy-option

Note 7. http://voxeu.org/article/helicopter-money

Note

http://www.lisbon-treaty.org/wcm/the-lisbon-treaty/treaty-on-the-functioning-of-the-european-union-and-comme nts/part-3-union-policies-and-internal-actions/title-viii-economic-and-monetary-policy/chapter-2-monetary-polic y/395-article-127.html

Note

$\mathrm{http} / / \mathrm{www}$.lisbon-treaty.org/wcm/the-lisbon-treaty/treaty-on-the-functioning-of-the-european-union-and-comme nts/part-3-union-policies-and-internal-actions/title-viii-economic-and-monetary-policy/chapter-2-monetary-polic y/395-article-127.html

Note 10. Basel III, B. C. B. S. The Liquidity Coverage Ratio and Liquidity Risk Monitoring Tools. Bank for International Settlements, 2013. Retrieved from http://www.bis.org/publ/bcbs238.htm

\section{Copyrights}

Copyright for this article is retained by the author(s), with first publication rights granted to the journal.

This is an open-access article distributed under the terms and conditions of the Creative Commons Attribution license (http://creativecommons.org/licenses/by/4.0/). 